\begin{tabular}{l}
\hline MIMESIS \\
Untiversitas \\
Ahmad Dahlan
\end{tabular}

\title{
TRADISI KEPUNGAN TUMPENG TAWON DESA MANGUNWENI KECAMATAN AYAH KABUPATEN KEBUMEN: KAJIAN FOLKLOR
}

\section{Yosi Sulastri}

Email : yosisulastri456@gmail.com

Program Studi Sastra Indonesia, Fakultas Sastra, Budaya, dan Komunikasi

Universitas Ahmad Dahlan, Yogyakarta

\section{Tristanti Apriyani}

Email : tristanti.apriyani@idlitera.uad.ac.id

Program Studi Sastra Indonesia, Fakultas Sastra, Budaya, dan Komunikasi Universitas Ahmad Dahlan, Yogyakarta

Article history

Received 28 June 2021

Revised 24 July 2021

Accepted 25 July 2021

Keywords

Folklore

Oral Literature

Tradition

Tumpeng Tawon
The purpose of this study aims to describe oral literature, describe oral literature, and determine the value of oral literature that can be achieved. This research is that the traditional oral literature of the tumpeng wasp siege has never been done in Mangunweni Village, Ayah District, Kebumen Regency. Oral literature has information that the public can utilize. The theory used in this research is the theory of the function of folklore by William R. Bascom and the theory of folklore proposed by Ruth Finnegan that oral literature has value in the phenomenon of human culture. The formal object of this research is the form, function, and value of oral literature. The material object in this study is oral literature in the tradition of the tumpeng wasp siege of the people of Mangunweni Village, Ayah District, Kebumen Regency. The analysis technique used is qualitative data analysis conducted by induction. The results showed that the oral literature of the tumpeng siege tradition is a type of oral tradition in myths and folk beliefs. The values contained in the tumpeng wasp siege tradition consist of religious values, harmony between humans, equality between humans, diversity, sincerity, unyielding, usefulness to others, and realizing ideals. The tumpeng Tawon siege tradition has a function as an assessment system, as a tool for ratifying cultural institutions and institutions, as an educational tool, and as a coercive and supervisory tool to always obey community norms.
Article history

Received 28 Juni 2021

Revised 24 Juli 2021

Accepted 25 Juli 2021

Keywords

Folklor

Sastra Lisan

Tradisi

Tumpeng Tawon
Tujuan penelitian ini untuk mendeskripsikan sastra lisan, menguraikan nilai sastra lisan, dan mengidentifikasi fungsi sastra lisan dapat tercapai. Alasan dilakukannya penelitian ini karena sastra lisan tradisi kepungan tumpeng tawon belum didokumentasikan di Desa Mangunweni Kecamatan Ayah Kabupaten Kebumen. Sastra lisan tersebut memiliki informasi yang dapat dimanfaatkan oleh masyarakat. Teori yang digunakan dalam penelitian ini yaitu teori fungsi folklor William R. Bascom dan teori folklor yang dikemukakan oleh Ruth Finnegan bahwa sastra lisan memiliki nilai di dalam fenomena budaya manusia. Objek formal penelitian ini adalah bentuk, fungsi, dan nilai sastra lisan. Objek material dalam penelitian ini adalah sastra lisan dalam tradisi kepungan tumpeng tawon masyarakat Desa Mangunweni Kecamatan Ayah Kabupaten Kebumen. Adapun teknik analisis yang digunakan adalah analisis data kualitatif yang dilakukan secara induksi. Hasil penelitian menunjukkan bahwa sastra lisan tradisi kepungan tumpeng tawon merupakan jenis tradisi lisan berupa cerita mitos dan kepercayaan rakyat. Nilai-nilai yang terkandung di dalam tradisi kepungan tumpeng tawon terdiri dari nilai ketuhanan, keharmonisan antarmanusia, kesamaan derajat antarmanusia, keberagaman, keikhlasan, pantang menyerah, kebermanfaatan kepada sesama, dan keprihatinan dalam menggapai cita-cita. Tradisi kepungan tumpeng tawon memiliki fungsi sebagai sistem proyeksi, sebagai alat pengesahan pranatapranata dan lembaga kebudayaan, sebagai alat pendidikan (pedagogical device), dan sebagai alat pemaksa dan pengawas agar norma-norma masyarakat akan selalu dipatuhi anggota.

This is an open access article under the CC-BY-SA license. 


\section{MIMESIS}

\section{PENDAHULUAN}

Berbicara tentang tradisi kepungan tumpeng tawon berarti berbicara tentang rentetan acara hajatan dalam masyarakat Jawa. Dalam sebuah tata urutan pernikahan ada sebuah prosesi yang disebut tahap masang tarub. Prosesi tersebut memiliki beberapa tujuan, salah satunya adalah untuk mewujudkan harapan dari tuan rumah.

Dalam sebuah acara hajatan, tuan rumah pasti menginginkan acaranya berjalan lancar. Tak hanya itu saja, tuan rumah juga berharap tamu yang datang akan melimpah ruah sehingga hidangan apa pun yang telah disiapkan tidak terbuang percuma. Harapan tersebut mendorong terciptanya sebuah tradisi bagi masyarakat di Desa Mangunweni, Kecamatan Ayah, Kabupaten Kebumen. Tradisi yang dimaksud adalah Kepungan Tumpeng Tawon atau Kepungan Tumpeng Mogana. Kepungan ini merupakan tradisi tumpengan yang dilakukan di daerah pesisir laut selatan, tepatnya di Desa Mangunweni, Kecamatan Ayah, Kabupaten Kebumen.

Proses pembuatan tumpeng tawon ini cukup unik yakni dengan menanak nasi di atas sebuah penanak (dandang) ditambahkan sarang tawon yang sudah diolah bersamaan dengan parutan kelapa, tempe, kangkung, ikan asin dan diberi bumbu tradisional seperti jahe, ketumbar, santan, dan daun salam. Sarang tawon tersebut akan diletakkan di tengah-tengah nasi, yaitu di antara bagian dasar tumpeng dan pucuk tumpeng. Setelah itu, tuan rumah biasanya akan mengundang para tetangganya khususnya para glidig untuk bersama-sama mengikuti acara kepungan dengan menyantap tumpeng tawon.

Tradisi budaya kepungan tumpeng tawon yang hidup di masyarakat Desa Mangunweni hadir sebagai sebuah rangkaian yang dilaksanakan ketika akan mengadakan hajatan, khususnya pernikahan. Fenomena tersebut tampak sebagai sebuah pemaksaan ketika melaksanakan tradisi. Namun, ketika dilihat dari proses pelaksanaannya, sastra lisan dari budaya kepungan tumpeng tawon tampak masih memiliki fungsi lain di dalamnya.

Oleh karena itu, diperlukan adanya penggalian data terhadap budaya tersebut supaya fungsifungsi di dalamnya tidak lenyap. Tradisi kepungan tumpeng tawon bisa saja punah apabila tidak didokumentasikan. Pendokumentasian tradisi lisan menjadi tulisan merupakan upaya yang dapat dilakukan dalam rangka pendokumentasian sastra lisan yang berkembang di masyarakat.

Melalui pendokumentasian, sastra lisan dapat berkembang sehingga mampu berperan dalam pemenuhan kebutuhan emosional serta intelektual masyarakat setempat. Apabila pendokumentasian dilakukan secara lebih mendalam, segala informasi yang tersembunyi dapat dibuka dan dimanfaatkan. Di samping itu, kehadiran sastra lisan juga dapat terus hidup bahkan diakui oleh masyarakat pemiliknya sehingga masyarakat luas dapat mengakui eksistensi sastra lisan tersebut.

Teori yang digunakan dalam penelitian ini yaitu teori fungsi folklor William R. Bascom dan teori folklor yang dikemukakan oleh Ruth Finnegan bahwa sastra lisan memiliki nilai di dalam fenomena budaya manusia. Bascom (1965: 3-20) dalam Endraswara (2013: 3) membagi fungsi folklor menjadi empat, yaitu 1) sebagai sistem proyeksi (proyective system), yakni sebagai alat pencermin angan-angan suatu kolektif, 2) sebagai alat pengesahan pranata-pranata dan lembaga-lembaga kebudayaan, 3) sebagai alat pendidikan (pedagogical device), dan 4) sebagai alat pemaksa dan pengawas agar normanorma masyarakat akan selalu dipatuhi anggota kolektifnya.

\section{METODE}

Objek formal dalam penelitian ini adalah bentuk, fungsi, dan nilai sastra lisan. Dalam hal ini sastra lisan yang terdapat pada tradisi kepungan tumpeng tawon Desa Mangunweni, Kecamatan Ayah, Kabupaten Kebumen. Objek material dalam penelitian ini adalah sastra lisan 


MIMESIS
VOL. 2. No. 2, Juli 2021
Universitas
Ahmad Dahlan

dalam tradisi kepungan tumpeng tawon masyarakat Desa Mangunweni Kecamatan Ayah Kabupaten Kebumen.

Penelitian ini merupakan jenis penelitian kualitatif. Penelitian kualitatif budaya digunakan supaya mampu melihat kondisi yang tidak mungkin dijangkau rumus-rumus kuantitatif. Pada penelitian ini metode pengumpulan data yang digunakan adalah wawancara mendalam dan observasi berperan. Proses analisis data penelitian ini dilakukan secara induktif, yakni dengan melakukan analisis data bersamaan dengan pengumpulan data penelitian.

Instrumen penelitian yang digunakan dalam penelitian ini adalah peneliti sebagai instrumen utama. Peneliti sebagai intrumen penelitian yang utama dikarenakan penelitian ini merupakan jenis penelitian kualitatif yang mengandalkan kemampuan peneliti secara langsung.

\section{PEMBAHASAN}

Desa Mangunweni merupakan salah satu desa yang berada di Kecamatan Ayah, Kabupaten Kebumen, Provinsi Jawa Tengah. Berdasarkan letak geografisnya, Desa Mangunweni berada di kawasan karst dengan sumber air yang cukup. Luas wilayahnya 400,55 ha, 78 ha di antaranya adalah hamparan sawah pertanian yang subur dan produktif dengan pola tanam padi dan palawija tiap tahunnya. Selain sawah pertanian, wilayah Desa Mangunweni terdiri dari tanah pekarangan seluas 106,7 ha, tanah tegalan 70 ha, tanah rakyat 135,76 ha, dan tanah lain-lain seluas 9,3 ha. Sistem pengairan yang digunakan hampir 100\% tadah hujan dan mengandalkan mata air yang ada seperti Kali Pengilon, Kali Pucung, Kali Siwlirang, Perkutukan, dan Kali Kedung Ijo (Jatmiko, dkk, 2020).

Komposisi penduduk Desa Mangunweni berjumlah 3416 jiwa yang terdiri dari 1750 lakilaki (51,2 \%) dan 1666 perempuan (48,8 \%). Dengan demikian, jumlah penduduk laki-laki lebih banyak bila dibandingkan jumlah penduduk perempuan di Desa Mangunweni. Kepadatan penduduk di Desa Mangunweni sebesar 864,09 jiwa/km² (Jatmiko, dkk, 2020).

\section{Tradisi Masyarakat Desa Mangunweni}

Masyarakat Desa Mangunweni memang menganut agama Islam, tetapi tradisi kejawen masih kerap dilaksanakan. Tradisi yang masih sering ditemui di wilayah Desa Mangunweni adalah berkaitan dengan daur hidup manusia, yaitu 3M (metu, manten, mati). Dalam tradisi lahiran, masyarakat masih melaksanakan mapati (empat bulanan), mitoni (tujuh bulanan), tujuh hari kelahiran, dan mudun lemah (turun tanah pada bayi umur 6 bulan). Pada tradisi pernikahan, masyarakat Desa Mangunweni masih melakukan rangkaian selamatan atau kenduri sebelum pernikahan tersebut dilaksanakan, yaitu resik (ziarah kubur), pasang ceblok atau tarub, kepungan tumpeng tawon, ijab kabul, dan panggih manten (pertemuan kedua pengantin beserta kedua orang tuanya). Kemudian, pada fase kematian, tradisi yang masih ada di Desa Mangunweni berupa nyaur lemah (peringatan hari kematian setelah jenazah dikubur), telung dina (peringatan tiga hari kematian), mitung dina (peringatan tujuh hari kematian), matang puluh dina (peringatan empat puluh hari kematian), nyatus dina (peringatan seratus hari kematian), pendak sepisan (peringatan satu tahun kematian), pendak pindo (peringatan dua tahun kematian), dan nyewu (peringatan seribu hari kematian). 


UAD
Universitas
Ahmad Dahlan

\section{Sastra Lisan Tradisi Kepungan Tumpeng Tawon}

Pelaksanaan tradisi kepungan tumpeng tawon di wilayah Desa Mangunweni didasari atas dasar mitos yang beredar di masyarakat. Melalui kepungan, warga meyakini bahwa orangorang yang mengikuti kepungan tersebut yaitu orang-orang yang akan mengirimkan undangan hajatan pernikahan adalah orang-orang yang mudah dikabulkan doanya.

Berdasarkan tipenya, sastra lisan dari tradisi kepungan tumpeng tawon merupakan folklor sebagian lisan. Tradisi kepungan tumpeng tawon merupakan sebuah kepercayaan rakyat yang pelaksanaannya berdasarkan informasi yang tersebar melalui mulut ke mulut. Tradisi kepungan tumpeng tawon juga tergolong dalam tradisi lisan berupa cerita mitos yang di dalamnya memuat kepercayaan bahwa melalui tradisi tersebut dapat sebagai sarana agar hal yang diinginkan terwujud atas izin dan kuasa Allah swt.

Adapun ciri-ciri pengenal sastra lisan dalam tradisi kepungan tumpeng tawon adalah sebagai berikut:

a. Penyebaran dan pewarisannya biasanya dilakukan secara lisan atau disertai gerak isyarat dan alat pembantu pengingat

b. Bersifat tradisional

c. Varian-varian sastra lisan Kepungan Tumpeng Tawon

d. Bersifat anonim

e. Mempunyai kegunaan dalam kehidupan bersama suatu kolektif

f. Menjadi milik bersama kolektif tertentu, setiap anggota kolektif yang bersangkutan merasa memilikinya

Secara umum ada tiga versi pelaksanaan tradisi tumpeng tawon. Pembeda antara ketiga versi tersebut terletak pada saat pelaksanaannya saja. Properti yang digunakan cenderung sama, yaitu nasi dan sarang tawon. Biarpun terdapat variasi, itu hanya sebatas tambahan atau pengurangan properti karena ketidaktahuan masyarakat.

\section{Nilai Pelaksanaan Tradisi Kepungan Tumpeng Tawon}

Pelaksanaan tradisi kepungan tumpeng tawon yang melibatkan banyak orang mampu memunculkan nilai-nilai luhur yang bermanfaat bagi masyarakat. Nilai-nilai yang terkandung dalam proses pelaksanaan tradisi kepungan tumbeng tawon adalah sebagai berikut:

\section{a. Bentuk Tumpeng}

Tumpeng apabila dilihat dari samping, akan membentuk tiga sudut dengan sudut di atasnya yang meruncing ke atas. Bentuk tersebut memiliki arti bahwa manusia berdoa dengan memohon kepada yang di atas, yaitu Allah swt. Bentuk tersebut juga dinilai sebagai upaya agar 


MIMESIS
VOL. 2. No. 2, Juli 2021
Universitas
Ahmad Dahlan

mendapatkan rida dari Allah swt dalam menjalankan kehidupan di dunia dan dalam rangka mewujudkan apa yang dicita-citakan.

\section{b. Peletakan Lauk di Tengah Tumpeng}

Peletakkan lauk yang tersembunyi di dalam tumpeng mengajarkan manusia untuk selalu menjaga rahasia. Apa pun keburukan orang-orang di sekitar mereka jangan dijadikan bahan gunjingan atau gibah. Biarkan apa yang menjadi jalan hidup orang tersebut menjadi konsekuensi atas apa yang dilakukan olehnya.

\section{c. Pengadukan Tumpeng Tawon}

Setelah selesai berdoa dengan dipimpin oleh tetua dari keluarga pihak pelaksana hajatan, tumpeng akan dibagikan kepada semua orang yang menghadiri kepungan. Sebelum dibagikan, tumpeng yang berisi lauk di dalamnya tersebut akan diaduk terlebih dahulu. Ketika nasi dan lauk sudah tercampur dengan rata, tumpeng tersebut akan dibagikan. Hal itu dimaksudkan supaya manusia harus menyatu.

\section{d. Kepungan}

Kepungan memiliki nilai luhur bahwa manusia sejatinya merupakan makhluk yang setara. Strata sosial maupun tingkat pendidikan tidak menjadi pembeda kehormatan antara manusia yang satu dengan yang lainnya. Warga yang menghadiri kepungan akan duduk sama rata dan menyantap hidangan yang sama tanpa membeda-bedakan terhadap pekerjaan atau jabatan yang dimiliki oleh mereka.

\section{Nilai Properti Tradisi Kepungan Tumpeng Tawon}

Nilai-nilai luhur tradisi kepungan tumpeng tawon juga terwujud dalam properti yang digunakan sebagai bahan pembuatan tumpeng tawon. Selain memiliki pesan, penggunaan bahan-bahan dalam pembuatan tumpeng tawon juga sebagai simbol harapan yang diinginkan oleh pelaksana hajatan. Harapan-harapan tersebut tecermin dalam sastra lisan yang melatarbelakangi tradisi kepungan tumpeng tawon dari properti yang digunakan.

Adapun nilai-nilai yang terkandung di dalam properti yang digunakan dalam pembuatan tumpeng tawon adalah sebagai berikut:

\section{a. Nasi}

Nasi merupakan sumber makanan utama di daerah Jawa. Asal nasi adalah beras yang memiliki makna sebagai sumber kewarasan. Beras merupakan harapan supaya pemilik hajatan mendapatkan kewarasan dan kesehatan dari Allah swt.

\section{b. Sarang tawon}




MIMESIS
VOL. 2. No. 2, Juli 2021
Universitas
Ahmad Dahlan

Penggunaan sarang tawon sebagai lauk utama didasarkan pada cita rasanya yang nikmat di samping makna dan harapan yang terselubung di dalamanya. Adapun makna dan harapan tersebut adalah agar prosesi hajatan yang akan berlangsung dihadiri oleh sanak saudara dan para undangan. Seperti halnya tawon yang berkerombol dan bersatu, kerukunan dari para tamu yang menghadiri undangan juga akan demikian.

\section{c. Kelapa parut}

Buah kelapa di wilayah Desa Mangunweni mudah dijumpai sehingga tidak mengherankan apabila buah kelapa menjadi salah satu bahan yang dipakai dalam olahan tumpeng tawon. Kelapa merupakan tumbuhan yang bisa dimanfaatkan keseluruhan pohonnya, mulai dari daunya yang muda (janur) bisa untuk membuat ketupat, daunnya yang setengah muda (blarak) bisa dijadikan sapu lidi, daunnya yang kering (klari) bisa dijadikan bahan bakar, dan buah kelapa yang tentunya bisa diolah menjadi berbagai menu masakan.

Kelapa parut yang digunakan merupakan kelapa yang masih muda. Filosofi penggunaan kelapa yang masih muda tersebut adalah bahwa ketika masih di usia muda, manusia harus senantiasa ikhlas menghadapi apapun. Jangan sampai mempunyai kesombongan dan iri hati supaya kelak bisa menjalani masa tua yang berguna bagi sesama.

\section{d. Santan kelapa}

Santan merupakan sari yang keluar dari kelapa yang sudah tua. Penggunaan santan kelapa memiliki nilai bahwa seorang manusia hendaknya bisa menjadi seperti kelapa, semakin tua semakin berguna. Kelapa yang sudah tua akan menghasilkan santan yang lebih banyak.

\section{e. Kangkung}

Sebagai bentuk usaha mewujudkan keinginan, seorang manusia harus memiliki sifat-sifat seperti yang dimiliki oleh kangkung. Ketika tumbuh, kangkung akan merayap dan merangkak. Meski begitu, kangkung bisa tetap tumbuh dan hidup. Sebagai seorang manusia, ketika menginginkan sesuatu harus berjuang dan jangan merasa malas supaya bisa menggapai apa yang diinginkan tersebut. Sifat kangkung yang tumbuh seperti tanpa tulang dan terlihat lemas juga memiliki nilai bahwa dalam manusia harus senantiasa bersikap tabah dalam menjalani setiap perubahan dalam hidupnya.

\section{f. Ikan asin}

Ikan asin merupakan ikan yang dikeringkan. Karena sudah kering, ikan asin menjadi simbol bahwa seorang manusia harus bisa mengeringkan hal-hal yang tidak baik sebagai upaya untuk menggapai cita-cita.

\section{g. Tempe}

Meskipun merupakan tambahan dalam olahan lauk di dalam tumpeng tawon, tempe merupakan sumber protein dan vitamin yang baik bagi tubuh.

\section{h. Daun salam}

Penggunaan daun salam sebagai bumbu dalam olahan tumpeng tawon karena daun salam mampu menambah cita rasa dan aroma. Selain itu, salam yang dalam bahasa Jawa berarti 


MIMESIS
VOL. 2. No. 2, Juli 2021
Universitas
Ahmad Dahlan

slanam slunum slamet mengandung sebuah harapan bahwa akan ada keselamatan yang berasal dari Allah swt.

\section{i. Jahe}

Jahe memiliki cita rasa yang mampu menghangatkan tubuh. Hangat tersebut mencerminkan mental semangat spiritual dalam usaha untuk menggapai apa yang diinginkan dan dikehendaki.

\section{j. Ketumbar}

Ketumbar merupakan salah satu rempah-rempah yang memiliki manfaat bagi organ tubuh. Salah satu manfaat ketumbar adalah untuk meredakan perut kembung.

\section{k. Merica}

Biarpun kecil, merica merupakan rempah-rempah yang dijual dengan harga tinggi. Rasa pedas yang dimiliki oleh merica menjadi harapan bahwa semangatnya pun akan sepedas rasanya. Di samping itu, ukuran merica yang kecil ternyata mampu memberikan manfaat yang besar karena bisa membuat siapa pun yang mengonsumsinya menjadi lebih semangat karena rasa pedas yang ditimbulkan.

\section{Fungsi Tradisi Kepungan Tumpeng Tawon}

\section{a. Sistem Proyeksi}

Tradisi kepungan tumpeng tawon mencerminkan tentang betapa pentingnya kebersamaan dan kerukunan yang tecermin melalui proses pelaksanaannya. Tumpeng tawon menggambarkan tentang masyarakat komunal yang hidup dalam keberagaman mampu bersatu dan bersama-sama dalam melaksanakan sebuah kegiatan dalam rangka peringatan salah satu fase daur hidup manusia.

\section{b. Alat Pengesahan Pranata-Pranata dan Lembaga-Lembaga Kebudayaan}

Sastra lisan dalam tradisi kepungan tumpeng tawon menjadi salah satu pengontrol budaya masyarakat Desa Mangunweni. Kepungan tumpeng tawon menekankan pada nilai moral yang ada di dalamnya sebagai bentuk pengesahan suatu norma khusus yang menata suatu rangkaian tradisi dalam masyarakat. Kemudian, norma khusus tersebut bisa menjadi warisan dari generasi ke generasi dalam masyarakat kebudayaannya.

\section{c. Alat Pendidikan (Pedagogical Device)}

Sastra lisan dari tradisi kepungan tumpeng tawon mengandung kekayaan lokal berupa nilai-nilai luhur yang bisa dijadikan sebagai sarana pendidikan bagi setiap manusia yang masih melaksanakan tradisi tersebut.

Adapun nilai-nilai pendidikan yang terkandung dalam tradisi kepungan tumpeng tawon adalah sebagai berikut:
a. Manusia harus beriman kepada Tuhan Yang Maha Esa
b. Manusia harus menjaga rahasia yang dimilikinya maupun orang-orang di sekelilingnya
c. Manusia memiliki kesamaan derajat
d. Manusia harus saling menghormati
e. Manusia harus memiliki sifat tenggang rasa terhadap sesama 


MIMESIS
UOL. 2. No. 2, Juli 2021
Universitas
Ahmad Dahlan

f. Manusia harus bisa memberikan manfaat

g. Manusia harus senantiasa ikhlas dan tabah dalam menghadapi ujian apa pun

h. Manusia semakin bertambah usia harus semakin bertambah kebermanfaatan dan daya pikirnya.

i. Manusia harus berjuang dan semangat dalam menggapai impian

j. Manusia harus mampu menahan diri dari nafsu angkara

k. Manusia harus menjaga persaudaraan dan kedamaian

\section{Alat Pemaksa dan Pengawas Agar Norma-Norma Masyarakat Akan Selalu Dipatuhi Anggota}

Dewasa ini, fungsi tradisi kepungan tumpeng tawon sebagai alat pemaksa cenderung mengalami degradasi. Masyarakat tidak lagi dipaksa untuk melaksanakan tradisi tersebut. Faktor yang menyebabkan hal itu terjadi salah satunya adalah perubahan sumber daya alam di wilayah Desa Mangunweni. Berdasarkan informasi yang diperoleh dari informan, kepungan tumpeng tawon bisa dilaksanakan apabila pada saat akan melakukan hajatan pihaknya bisa menemukan bahan baku utama berupa sarang tawon. Ketika tidak bisa memeroleh sarang tawon, maka kepungan tumpeng tawon bisa saja tidak dilaksanakan. Hal itu terjadi karena sulitnya menemukan sarang tawon pada kurun waktu dewasa ini

\section{KESIMPULAN}

Berdasarkan hasil penelitian dan pembahasan tentang tradisi kepungan tumpeng tawon di Desa Mangunweni, Kecamatan Ayah, Kabupaten Kebumen berkaitan dengan bentuk, nilai, dan fungsi; maka dapat disimpulkan bahwa tradisi kepungan tumpeng tawon merupakan salah satu bagian dari rangkaian tradisi pada proses pernikahan. Berdasarkan bentuknya, sastra lisan dari tradisi kepungan tumpeng tawon merupakan folklor sebagian lisan.

Nilai-nilai yang terkandung dari tradisi kepungan tumpeng tawon terdiri dari nilai ketuhanan, keharmonisan antarmanusia, kesamaan derajat antarmanusia, keberagaman, keikhlasan, pantang menyerah, kebermanfaatan kepada sesama, dan keprihatinan dalam menggapai cita-cita.

Empat fungsi folklor di dalam tradisi kepungan tumpeng tawon adalah sebagai sistem proyeksi; sebagai alat pengesahan pranata-pranata dan lembaga kebudayaan. Sastra lisan dalam tradisi kepungan tumpeng tawon menjadi salah satu pengontrol budaya masyarakat Desa Mangunweni; sebagai alat pendidikan (pedagogical device); sebagai alat pemaksa dan pengawas agar norma-norma masyarakat akan selalu dipatuhi anggota. Kepungan tumpeng tawon menjadi salah satu sarana bagi warga Desa Mangunweni dalam mewujudkan rasa syukur pada saat akan melaksanakan hajatan pernikahan.

\section{DAFTAR PUSTAKA}

Ananda, R. (2017). Kajian fungsi sastra sisan Kaba Urang Tanjuang Karang pada pertunjukan Dendang Pauah. Semantik, 4 (2). 92-122. Diambil dari https://ejournal.stkipsiliwangi.ac.id. 
Budianto, V. I. M. (1999). Realitas dalam simbol "Wiwahan" atau simbol "Wiwahan" dalam sealitas: suatu refleksi terhadap tradisi Jawa. Wacana, 1 (1). 119-132. Diambil dari https://brill.com.

Danandjaja. (1986). Folklor Indonesia. Jakarta: Pustaka Grafitipers.

Endraswara, S. (2013). Folklor nusantara: hakikat, bentuk, dan fungsi. Yogyakarta: Penerbit Ombak.

Endraswara, S. (2017). Metodologi penelitian kebudayaan. Yogyakarta: Gadjah Mada University Press.

Jatmiko, A., Masruri, A., Rosyadi, M. M., Istikomah, T. Setiyani, H., Noviyana, E., Lestyari, T., Salamah, U., Ikhsanah, Z. (2020). Laporan Kelomok Pelaksanaan Kuliah Kerja Nyata (KKN), Institut Agama Islam Nahdlatul Ulama (IAINU).

Muslimin, M. F., \& KM, J. U. S. (2019). Aspek kelisanan dan fungsi pada Mantra Bato Peter, mitos menstruasi, mantra prosesi drojogan, dan sastra lisan lawas. Totobuang, 7 (2). 349-360. Diambil dari https://totobuang.kemdikbud.go.id/jurnal/index.php/totobuang/article/view/150/104

Puspitasari, A. (2012). Kajian folklor tradisi merti Dhusun di Dusun Tugono Desa Kaligono Kecamatan Kaligesing Kabupaten Purworejo. Skripsi, tidak diterbitkan, Universitas Muhammadiyah Purworejo.

Wiranata, I. G. A. B. (2011). Antopologi budaya. Bandung: PT Citra Aditya Bakti. 